\title{
A Review of Works Done Regarding the Impact of Bunch Cover Application in Banana
}

\section{Purnima Pathak*, Ranjit Kumar Bhattacharyya, Bhupen Kumar Baishya, Utpal Das and Jugabrata Das}

\author{
College of Horticulture, Assam Agricultural University, \\ Jorhat, Assam - 785013, India \\ *Corresponding author
}

\section{A B S T R A C T}

Keywords

Bunch cover, Banana, Quality and Quantity.

Article Info

Accepted:

21 June 2017

Available Online:

10 July 2017

\begin{abstract}
Intercultural practices in banana contribute immensely to better yield, quality and appearance regarding the market value of the fruits. Bunch covering being one of the most important practices, has high influence in improving all aspects, fetching a better price to the banana growers. Bunch covering, traditionally done by wrapping bunch with dry leaves, is now upgraded by the use of synthetic materials which has opened new windows with an attempt to view better scenery in banana production, which is influenced by several biotic and abiotic factors. Among abiotic factors, temperature is considered to have profound influence on quality and quantity of fruits. Bunch covering alters the temperature within the covers, indirectly leading to faster assimilates translocation and better fruit filling. Apart from this, bunch covers serves in enhancing the external appearance of fruits both by protecting it from pest infestation and harvesting and handling bruises. This practice also helps in overcoming the barriers in maintenance of ecological balance as it can reduce the use of chemical pesticides in the crop. Moreover, bunch covers being easily available and applicable encourages the farmers for its quick adoption. Growing popularity of bunch covering has earned interests in the field of researches also. Several researches has been done so far, to observe the influence of various bunch covers irrespective of colour, material, shape on various cultivars of banana and are found very influential.
\end{abstract}

\section{Introduction}

Banana farming is one the major occupations among the fruit growers in the world. Reason behind its popularity is the income driven from it. However, it mainly depends on the correct choice of cultivar, inputs applied and proper intercultural practices performed.

Banana crop needs to be protected from the adverse climatic phases and pest harming its production, appearance and quality of the fruits. Among the various intercultural practice followed in banana, bunch covering has gained a lot of importance because of its significance in overall improvement of fruit and reducing the crop duration.

The concept of bunch cover aroused from the practice of wrapping the newly emerged bunches with the dry banana leaves from the plant itself. The covers are usually applied after full emergence of bunches. Removal of the male bud is necessary before application of sealed covers. However, if open end covers are used this necessity can be filled at a later 
stage also. Removal of the flowers at the tip is also recommended as the atmosphere under the inappropriately ventilated covers may cause rotting of the flowers which gradually head towards the fruits. Till date, various materials have been used for bunch covering in banana. Among them polyethylene, polypropylene and jute are more popular.

Bunch covering being an eco-friendly practice, reduces the risks involved in use of chemical pesticides. Moreover, bunch covers helps in shortening the harvesting time enhancing the growth factors. The influence of bunch covers in maturity, yield, quality and appearance of banana are reviewed in the following subheads.

\section{Influence of bunch covers on maturity of banana}

A mean monthly temperature of $21^{\circ} \mathrm{C}$ or less resulted in the decrease of growth with reduced leaf production and delayed flowering (Purseglove, 1972). Haque (1984) reported that the number of days required from planting to flowering and planting to harvesting (crop period) depend on climatic factors like temperature.

Bunch covers have been used to protect bunches from low temperatures, especially in temperate countries (Gowen, 1995; Robinson, 1996; Harhash and Al-Obeed, 2010). Indeed bagging has been shown to reduce winter stress under supra-optimal condition which resulted in early fruit maturation (Jia et al., 2005). Banana bunch covers changes the microclimate by inducing slightly warmer condition and thus have beneficial effect on maturity, yield and quality of fruit (Mukharjee, 2006).

In an experiment in New South Wales, Turner (1984) observed that a bunch emerging in April takes six months or more to mature, while one emerging in November takes only three months. So temperature has a big influence on the rate of fruit growth, hence the use of bunch covers, which are thought to warm the fruit, thereby increases growth rate. It was also proven that winter fruit fills faster under covers which accelerated bunch development, resulting in overall shorter cycle (Daniells et al., 1987).

Han et al., (1990) reported that low temperature delayed flower bud initiation, differentiation, bunch emergence and maturity of 'Dwarf Cavendish' banana. According to Shanmugavelu and Balakrishnan (1980), age is the dominant factor which determines the flowering time of banana. Banana is a day neutral plant but temperature plays a major role in controlling flowering. The number of days required from flowering to harvest are influenced by several factors such as number of functional leaves retained (Satyanarayana, 1985 and Kothavade et al., 1985) and time of bunch emergence (Robinson and Nel, 1986). The time required from bunch emergence to harvest for 'Dwarf Cavendish' appeared to be 128 days (Madhava Rao, 1984) and 130 days (Lodh et al., 1971). The findings of Green and Kunhe (1975), revealed a sigmoid relationship between bunch maturation period and temperature, with minimum response at $11^{\circ} \mathrm{C}$, maximum at $29^{\circ} \mathrm{C}$ and average at $20^{\circ} \mathrm{C}$.

In tropical countries no differences were observed in yield, finger length or shooting to harvest interval between covered or uncovered bunches. Here, benefits were related more to blemish control and reduction of pest damage (Rodrigues et al., 2008).

In a trial conducted in National Research Centre for banana, Tiruchirappalli, the use of polypropylene bunch sleeves in summer crop of 'Ney Poovan' and 'Rasthali' bananas resulted in early fruit maturity (111.4 days and 104.9 days, respectively) as compared to 
the uncovered bunches (120.3 days and 114.2 days, respectively). This trial also reported that in 'Grand Naine', the time interval between bunch emergence and harvest of bunch was significantly reduced in all the bunches covered with sleeves and fruit maturity was advanced by 7.1 days in bunch covered with blue polypropylene (108.7 days) as against 115.8 days recorded in uncovered control (Anon., 2012).

In 'Dwarf Cavendish' and 'Giant Cavendish', use of blue polyethylene covers consistently reduced the time between the bunch emergence and harvest. The reduction in time ranged from 4.3 days to 14 days (Heenan, 1973).

Choudhury et al., (1996) reported that in 'Dwarf Cavendish' banana, crop duration (particularly days taken from planting to flowering and from flowering to physiological maturity of fruits) and production per day were significantly influenced by bunch cover treatments. The lowest days taken for maturity from flowering was recorded in the bunch covered with white polyethylene and mustard oil cake (106.33 days) as compared to untreated bunches (142 days). Rodrigues et al., (2001) reported that the harvest time of the bunch with cover was 12 days earlier than the one without cover.

In high density planting $(1.2 \times 1.2 \mathrm{~m})$ of banana cv. Robusta, the use of bunch covers significantly reduced the time of maturity of bunches from 151.6 days (uncovered bunch) to 139.4 days (Reddy, 1989).

In a trial with 'Dwarf Cavendish' plants, newly emerged bunches which were enclosed in blue and white polyethylene covers 36 days after flower emergence resulted in a early harvest of 2-3 weeks than the uncovered bunches (Robinson and Nel, 1984). According to Stevenson (1976), with summer bunch covering, covering materials irrespective of colour substantially accelerated or delayed bunch filling, but in winter the use of transparent material speeded up the filling and harvesting of banana bunches.

Similarly, Cunnen and Entyre (1988), Reddy (1989), Patil et al., (1989) and Anon. (1993), observed that bunch covers significantly reduced the time taken for bunch maturity i.e. from flowering to harvest. They also reported that the advancement of bunch maturity obtained in covered bunches were due to increase in temperature in and around the bunch. In Musa accuminata (AAA), the removal of the lower hands and bunch bagging reduced the number of days required from shooting to harvest (Irizarry et al., 1992). Temperatures under the cover were $2^{\circ} \mathrm{C}$ to $6^{\circ} \mathrm{C}$ warmer and during cool times of the year, this increased fruit length and hastened fruit filling (harvest duration was 4 to 14 days earlier)(Daniells and Lindsay, 2005).

\section{Influence of bunch covers on yield characters of banana}

The shooting in winter planted plantation commences in the winter period producing fruits of inferior in size as well as low yield (Sarkar, 2014). Lodh et al., (1971) opined that in 'Dwarf Cavendish' the fruit length, girth, whole weight and pulp-peel ratio of fruits under cover increased throughout its growing period. The temperature variation accounted for more than 80 per cent of the variation in fruit growth rate. Deviation from extended growth rate occurred in cold season, when temperature becomes the limiting factor. In winter, the effect of low temperature on the ceasation of growth becomes more distinct; the rate of growth increases with the increased rate of temperature in spring. 
Khataniar (1989) reported that due to low temperature in January, the yield of 'Dwarf Cavendish' banana was significantly lower than that of June flowering. When the mean daily temperature is below $14^{\circ} \mathrm{C}$, there is no vegetative growth, while some fruit growth still continues; hence temperature threshold for fruit growth is lower than that for the vegetative growth (Turner and Lahav, 1983). This reduction in fruit growth might be overcome with the use of bunch covers.

Bunch covers of various colours and conditions (perforated and non-perforated) have been extensively used in both tropical and subtropical banana growing countries with the aim of improving yield and quality (Stover and Simmonds, 1987; Robinson, 1996).

Haque (1984) obtained bigger sized fruits from the bunch which received warm temperature during the development of fruit. Cuneen and Entyre (1988), Reddy (1989), Patil et al., (1989) and Anon. (1993) reported that, the bunch cover with different coloured polyethylene bags significantly increased the fruit length, girth and weight over uncovered fruits.

During the day, the temperature inside the bags was up to $10^{\circ} \mathrm{C}$ higher than the outside air temperature (Cuneen and Entyre, 1988).

The yield of banana was influenced by the time of flowering (Singh, 1976) besides many other factors like number of functional leaves (Satyanarayana, 1985) and vigorous initial growth of the plant (Swennen and Lanhe, 1985).

According to Heenan (1973), slight indication of increased yield of 'Dwarf Cavendish' was obtained by using blue polyethylene cover. The use of polyethylene covers increased the bunch weight by $1.6 \mathrm{~kg}$ than the uncovered bunches in 'Dwarf Cavendish' banana
(Amani and Avagyan, 2014).

Covered banana bunches in 'Dwarf Cavendish' registered a bunch weight of 14.5 $\mathrm{kg}$ as compared to uncovered bunches weighing $11.50 \mathrm{~kg}$ (Mukharjee, 2006). The increase in fruit size and weight obtained in covered bunches were due to increase in temperature in and around the bunch (Reddy, 1989).

In 'Grand Naine' bunch covered with blue polypropylene sleeves recorded the highest bunch weight $(35.68 \mathrm{~kg})$, fruit weight $(221.7$ g) followed by white polypropylene bunch sleeves which recorded a bunch weight of $34.5 \mathrm{~kg}$ whereas, the uncovered bunch recorded the least bunch weight $(32.88 \mathrm{~kg})$ with average finger weight of $198.5 \mathrm{~g}$. Results also indicated that, in 'Ney Poovan' and 'Rasthali', polypropylene bunch sleeves enhanced the bunch weight $(16.3 \mathrm{~kg}$ and 18.5 $\mathrm{kg}$, respectively) and finger weight $(89.9 \mathrm{~g}$ and $205.4 \mathrm{~g}$, respectively) as compared to the lowest recorded bunch weight $(14.20 \mathrm{~kg}$ and $16.9 \mathrm{~kg}$, respectively) and finger weight (79.6 $\mathrm{g}$ and $183.7 \mathrm{~g}$, respectively) in the uncovered bunches (Anon., 2012).

In high density planting $(1.2 \times 1.2 \mathrm{~m})$ of 'Robusta' banana, the use of bunch covers significantly increased the finger weight and finger diameter $(234.9 \mathrm{~g}$ and $4.3 \mathrm{~cm}$, respectively) as compared with the uncovered bunches with a finger weight and finger diameter of $199.8 \mathrm{~g}$ and $3.8 \mathrm{~cm}$, respectively (Reddy, 1989).

In 'Dwarf Cavendish' the highest bunch weight $(15.25 \mathrm{~kg})$ and yield $\left(67.78 \mathrm{t} \mathrm{ha}^{-1}\right)$ was obtained from the use of white polyethylene cover + mustard oil cake compared to uncovered bunches $\left(7.37 \mathrm{~kg}\right.$ and $32.74 \mathrm{t} \mathrm{ha}^{-1}$, respectively) (Choudhury et al., 1996).

In a trial with 'Dwarf Cavendish' plants, Robinson and Nel (1984) reported that newly emerged bunches which were enclosed in 
blue and white polyethylene covers 36 days after flower emergence resulted in a high bunch weights (56 kg and $55 \mathrm{~kg}$, respectively) as compared to the uncovered bunches (49 $\mathrm{kg}$ ). The trial also resulted in higher finger weight (187 $\mathrm{g}$ and $174 \mathrm{~g}$, respectively) in bunches enclosed in blue and white polyethylene as compared to the uncovered bunches (147 g).

Hasan et al., (2001) observed increase in temperature in bunches bagged in transparent, blue and red polyethylene than the one in open condition. He also found that in 'Giant Governor', light interception was maximum in transparent polyethylene cover among the treatments. The highest fruit size was also obtained in transparent polyethylene cover.

Reports from a field investigation at North 24 Pargana district of West Bengal, in 'Grand Naine', revealed that bunch covering with 20 per cent perforated polyethylene showed significantly increased yield (44.23 $\left.\mathrm{t} \mathrm{ha}^{-1}\right)$, fruit weight $(111.29 \mathrm{~g})$, bunch weight (15.91 $\mathrm{kg}$ ) compared to the uncovered bunches (Pathak and Mitra, 2014).

In Musa accuminata(AAA), the bunches covered with dursban treated or untreated perforated polyethylene bags yielded 10.539 $\mathrm{kg} \mathrm{ha}{ }^{-1}$ more than the uncovered bunches during a 40 month production period. The removal of three lower hands and bunch bagging increased size of individual fruits in distal hand, thus upgrading fruit quality (Irizarry et al., 1992).

Cunnen and Entyre (1988), Reddy (1989), Patil et al., (1989) and Anon. (1993) reported that, bunch covers with different coloured polyethylene bags significantly increased the fruit length, girth and weight over uncovered fruits. During the day, the temperature raised within the cover which lead to the changes in the yield and yield attributing components
(Cuneen and Entyre, 1988).

In subtropical banana growing countries, with cold winters and strong winds, the benefits of bunch covers are both physiological (improved microclimate) and physical (larger fruit and reduced chaffing from dust and leaves). Daniells (1994) and Johns (1996), reported increased finger length, higher yield and shorter flower to harvest interval in various subtropical countries.

Bunch trimming (removal of male bud and several distal hands from bunches soon after flowering) and double covering (use of 2 bunch covers simultaneously) of banana bunch that emerged during winter in South Wales showed an increase in size of fingers (Johns, 1996).

However, the effect of fruit bagging, especially in the tropics, on size, maturity, skin colour among other postharvest parameters has been contradictory, which may reflect differences in the type of bag used, fruit age at bagging, fruit and cultivar response, prevailing climatic conditions and conditions of holding fruit after harvest (Johns and Scott, 1989; Amarante et al., 2002 and Narayana et al., 2004). The effect of banana bunch covering especially in the tropics has demonstrated inconsistent results on the size of fruit. However, double covering increased finger weight of the top six hands by 4 per cent $(\mathrm{P}<0.01)$. Double covering of bunches did not significantly affected the yield of extra-large fruits (Johns, 1996).

Kutinyu et al., (2014) working on bunch covering of banana for two consecutive years opined that, the temperature loggers placed in all treatments for both seasons showed higher temperatures inside the bags than the outside air temperature in most of the treatments with the exception of treatments with white, green and blue perforated bags in some seasons. For treatments with cv. Grand Naine, average 
temperatures inside the bags ranged from $26.9^{\circ} \mathrm{C}$ to $29.6^{\circ} \mathrm{C}$ in 2012 and $28.1^{\circ} \mathrm{C}$ to $31^{\circ} \mathrm{C}$ in 2013. Treatments with $\mathrm{cv}$. Williams had average temperatures inside the bags ranging from $25.7^{\circ} \mathrm{C}$ to $29.6^{\circ} \mathrm{C}$ in 2012 and $26.5^{\circ} \mathrm{C}$ to $30.5^{\circ} \mathrm{C}$ in 2013 .

During both the years, bagging treatments did not considerably improved weight of hands, banana finger weight, total fruit weight, marketable weight, and percentage marketable fruit weight and box stem ratio of 'Grand Naine'.

In the same study, bagging treatments tended to be inconsistent between the two seasons. In cv. Williams, during 2013, bagging treatments improved weight of hands, whereas no significant differences were observed on weight of hands during 2012. Bagging of banana bunches reduced defects in both seasons, though no substantial responses were shown in marketability percentage. In 2012/2013, marketable weight tended to be inconsistent with blue perforated polyethylene and green non-perforated significantly increasing marketable weight. Both green and blue perforated bags improved box stem ratio. Bagging treatments increased 'Williams' cultivar's yield per hectare in both seasons.

\section{Influence of bunch covers on quality characters of banana}

Collins (1960) reported that longer night, cooler temperature produced fruits with higher acid content. In fact, low temperature caused khaki discolouration of skin, inhibition of starch-sugar conversion and decline in ascorbic acid content in banana (Anon., 1969). Dhua et al., (1988) explained that fruit physiological and biochemical changes were influenced by temperature.

Khataniar (1989) found that banana fruits which grew and developed in higher temperature $\quad\left(24.55^{\circ} \mathrm{C}-31.05^{\circ} \mathrm{C}\right)$ have significantly higher pulp weight, peel weight, pulp-peel ratio, TSS, sugar-acid ratio and lower reducing sugar, non-reducing sugar and titrable acidity than that of winter harvested fruits which received low temperature $\left(14.34^{\circ} \mathrm{C}-25.82^{\circ} \mathrm{C}\right)$.

Sarmah (1976) reported that the ascorbic acid content of various banana cultivars do range between $4.2 \mathrm{mg}$ and $10.5 \mathrm{mg}$ per $100 \mathrm{~g}$ of finger weight. Number of observations revealed that there was a deceasing trend of ascorbic acid content in banana, during maturity (Jayaraman and Ramanuja, 1986; Tripathy et al., 1981 and Soenapa et al., 1986).

Banana fruits contain high levels of starch (15-39\%) which undergo a drastic biochemical change during ripening (Lizada et al., 1990). The change includes a marked increase in soluble sugars and organic acids, chlorophyll breakdown and polymerization of phenolic compounds in the ripening fruits (Pawlowski et al., 1994).

Improved quality includes appealing skin colour, reduced sunburn, reduced fruit splitting, which can be increased by the use of bunch covers to protect bunches from low temperatures, especially in temperate countries (Gowen, 1995; Robinson, 1996). This is due to enhanced physiological and metabolic activities provided by the microclimate created by bagging (Johns and Scott, 1989).

Protection of young bunches of fruits with polyethylene bag covering is one of the measures use in the producer countries (Amani, 2005). The use of polyethylene bunch covers is widespread throughout the commercial banana growing regions of the world. They are also commonly used to protect export market intended plantain fruit 
during development. In southern Queensland and New South Wales, the insulation of the bunch is essential for enhancing fruit quality during the cooler months. Bunch covers of various colours and conditions have been extensively used in banana growing countries with the aim of improving yield and quality (Stover and Simmonds, 1987; Robinson, 1996).

In cv. Grand Naine finger characters and fruit quality parameters like pulp-peel ratio (3.08) and TSS $\left(27.8^{\circ}\right.$ Brix) were the highest in bunches covered with blue polypropylene sleeves (Anon., 2012). This was supported by studies of Sarkar (2014) who worked in 'Grand Naine', and found that the covered bunches had more total soluble solids than the uncovered bunches.

Choudhury et al., (1997) working in 'Dwarf Cavendish', reported best quality fruits (21.67\% TSS, sugar-acid ratio of 71.33, ascorbic acid content of $0.43 \mathrm{mg}$ per fresh weight and protein content of $2.03 \%$ ) were obtained from the bunch covered with white polyethylene and mustard oil cake treated bunches as compared to uncovered bunches (16.33\% TSS, sugar-acid ratio of 65.82 , ascorbic acid content of $4.25 \mathrm{mg}$ per $100 \mathrm{~g}$ fruit weight and protein content of $1.92 \%$ ).

A field investigation at North 24 Pargana district of West Bengal, in cv. Grand Naine, suggested that the use of bunch covering with 15 per cent perforated polyethylene resulted maximum TSS-acid ratio of fruit (67.77) compared with fruits of uncovered bunches (41.07) (Pathak and Mitra, 2014).

Bunch covering had no significant $(\mathrm{P}>0.05)$ effect on the pulp-peel ratios of fruits of $\mathrm{cv}$. Williams at harvest and during ripening (Muchui et al., 2010). It was seen that in bananas, the pulp portion continues to grow even in the later stages of maturation (Turner, 1997; Nakasone and Paul, 1998). However, this may be due to the different types of bags for bunch covering used, the age of the fruit at covering, fruit and cultivar response, the climatic conditions and also the conditions in which fruit is held pre and post-harvest and all these factors influence fruit quality (Amarante et al., 2002). Internal attributes such as taste, texture, sweetness, aroma, acidity, flavour, shelf life and presumed nutritional values of the fruit are important in ensuring repeated buys (Hewett, 2006).

Muchui et al., (2010) obtained that both starch and total soluble solids (TSS) at harvest and during ripening were not influenced significantly ( $p>0.05)$ by bunch covers. Starch reduced as ripening progressed while TSS increased as expected in ripening banana (Stover and Simmonds, 1987). Unripe bananas have large amount of starch (20\% to $25 \%$ ) in the pulp of fruit (Nascimento et al., 2006).

During the climacteric stage, the accumulated polysaccharide is rapidly degraded and most of it is converted into soluble sugars which form a large proportion of TSS in the banana (Marriot, 1980 and Seymour et al., 1993). Contradictory results were found by Muchui et al., (2010) which revealed that bagging did not influenced the starch formation during banana growth and starch degradation during ripening.

\section{Influence of bunch covers on other characters associated with banana}

External appearance, internal quality and marketability of bananas are influenced by several factors, including favorable environmental condition like temperature and pre-harvest production practice like bunch covers application. The pre-harvest production processes are affected by various environmental factors. Temperature being the most marked one amongst them. 
When tropical and subtropical fruits are exposed to low temperature injury, abnormal ripening, pitting, water-soaked areas and increased susceptibility to fungal infection occurs (Sharom et al., 1994). Cellular membrane damage is a typical symptom that occurs during early low temperature injury (Marangoni et al., 1996). It has been reported that the browning (low temperature injury symptom) in banana peel is caused by the oxidation of polyphenols caused primarily by polyphenol oxidase (Yang et al., 2000). Nguyen Thuy et al., (2003) reported that when the banana fruits are exposed to low temperatures, an increased activity of both phenylalanine ammonia lyase and polyphenol oxidase occurs, which negatively affects the fruit quality.

There are also a range of fruit physiological disorders resulting from low temperature exposure during certain plant development stages. For example, if the fruit is exposed to chilling temperatures during development, a discoloration of the vascular tissue occurs, leading to brown stripes which mask the normal yellow colour of the fruit when ripe. This is called "under-peel discoloration" (Robinson, 1993). Some of these physiological disorders can be avoided to a limited extent by adapting some of the agricultural practices; such as using different fruit protection bags in the winter from those in the summer.

Uneven de-greening, a kind of ripening disorder in banana peels, occurs seasonally in Taiwan, where it is a serious quality problem. The affected bananas are characterised by either partial or delayed yellowing of the peels in mild cases or by remaining green in severe ones following ethylene treatment. Some factors suspected for its occurrence include chemical hazards, virus infection, and overuse of nitrogen fertiliser, genetic factors and low temperature. Temperatures below $20^{\circ} \mathrm{C}$ in winter during bunch development and genetics have been so far considered as the major contributory factors of uneven degreening. An integrated strategy was designed to reduce uneven de-greening, including the use of cultivars of low susceptibility to the disorder, elimination of affected plants from stock nurseries which supply suckers for micro propagation programs and the use of brown paper covers instead of blue polyethylene covers for bunch protection (Chao et al., 1998).

The external appearance includes key attributes such as colour, shape, size and freedom from defects. The internal attributes such as taste, texture, sweetness, aroma, acidity, flavour, shelf life and presumed nutritional values of the fruit are important in ensuring repeated buys (Hewett, 2006; Shewfelt, 2009). The physical appearance of the peel is especially important in the highly competitive export markets and in some local niche and up markets like the supermarkets. Buyers in these prime markets require consistent supplies of uniform coloured fruit with blemish-free peels. Banana bunch covers allow for production of high quality banana fruits that are not bruised, and hence have acceptable visual appearance.

Consumers generally use visual quality to purchase fresh produce (Shewfelt, 1999 and Shewfelt, 2009). Market returns for bananas in international markets are usually greatest for large fruit that are blemish-free (Johns, 1996). The supply of blemish-free fruit is difficult to obtain due to various types of mechanical injury and insect damage imparted on the delicate peel surface during growth and development, with wind and insects being the principal agents of this damage (Anon., 2003). Pre-harvest insect feeding has been shown to be a main cause of peel damage to banana fruits (Shanmugasundaram and Manavalan, 2002). 
However, bagging of bananas with bags impregnated with insecticides has been shown to protect fruits from insect attack (Amarante et al., 2002). Wind blows dust and debris which hits the delicate outer skin causing cellular damage and subsequent fruit scarring. Considerable physical injury and damage to the fruit peels can also be caused by the blowing of adjacent leaves and rubbing of leaf petioles onto the developing bunch (Anon., 2003). This chaffing from leaves during growth has also been reported to be eliminated by use of bunch covers (Weerasinghe and Ruwapathirana, 2002).

Bunch covers provides protection to the fruit surface against pathogens, wind damage, leaf and petiole scarring, dust, light hail, sunburn, bird feeding and handling damage during harvest and transport.

A significant reduction in peel surface damage from insect pests may be obtained by covering the plantain or banana bunch shortly after pollination. Moreover, the incidence of postharvest anthracnose disease has been shown to be significantly less on fruit from sleeved bunches. The net effect of bunch cover use is better fruit quality and increased marketable yield. In Panama, Banana thrips (Chaetanaphothrip sorchidii) has been controlled with bunch cover application in 2-3 weeks after formation of fruits (Stover, 1972).

In addition, bunches were protected against the pests and diseases such as beetles, pitting, anthracnose, tip end rot, cigar end rot, brown spot and diamond spot (Amani, 2005). The use of polyethylene bags on bunches, was also advocated as a control measure of diseases in Cameroon, India and Palestine (Jones, 2000).

Robinson and Nel (1982) used different bunch cover combinations during the summer at Burgeshall, South Africa. Bunches of
'Dwarf Cavendish' bananas arising from flowers emerging in late November to early December were enclosed in brown paper bags of polyethylene covers of different colour combinations, this was after bunches emerged and flower bracts started to open up. The proportion of clean fingers was low (9-12\%) with up to 48 per cent damaged by thrips and mites. Fruit surface temperatures especially in the morning and relative humidity in the afternoon were highest in polyethylene bags, resulting in the highest percentages of soft rots $(15 \%)$ and uneven ripening.

The percent of fruit damage was found to be reduced to 31.25 per cent in covered fruits as compared to 59 per cent in uncovered bunches. The number of scars in the leaf $/ 5$ $\mathrm{cm}^{2}$ reduced to 5 as compared to 6.75 in uncovered bunches (Mukharjee, 2006). The skin of the fruit from covered bunches was significantly softer than that from uncovered bunches. Covered fruits in general were much more attractive, being free of skin blemishes caused by insects, fungi, birds, the abrasive action of leaves, or spray residues. Covers were also very effective in reducing banana fruit fly (Strumeta musae) infestation (Heenan, 1973).

In a trial with 'Dwarf Cavendish' plants, newly emerged bunches which were enclosed in blue and white polyethylene covers 36 days after flower emergence resulted in reduction of mechanical blemishes from 20 to 29 per cent and 17 per cent, respectively (Robinson and Nel, 1984).

Reports of Pathak and Mitra (2014), suggested the use of 20 per cent perforated polyethylene bunch covers in cv. Grand Naine to control scarring beetle infestation and quality banana production. Bunch covers also reduced the gradient of temperature across the bunch, and fruits from covered bunches were more uniform than that from uncovered bunches (Turner, 1984). 
In an experiment held in Central Kenya in cv. Williams, bagged fruits had minimal bruises ( 2 to $5 \%$ ) and were significantly cleaner from dust, spider webs, bird droppings at harvest compared to unbagged fruits $(>50 \%)$. The covered fruits were therefore visually appealing, cleaner compared to unbagged fruits (Muchui et al., 2010). This finding agrees to that of Weerasinghe and Ruwapathirana (2002) who found that banana fruits grown under covers had no blemishes at all and were attractive to customers at a glance while unbagged fruits had black spots and blemishes caused by thrips and freckle fungi attack. However, few of the uncovered fruits suffered sunburn which adversely affected fruit quality especially during the hot season. Top hands were mainly effected specially those which were covered with dull polyethylene covers due to more heat absorbed inside the cover as compared to the shiny blue covers which may have reflected some heat away (Muchui et al., 2010). Elsewhere, bagging of banana resulted in sun scorching of the fruits irrespective of colour of the bunch covers (Weerasinghe and Ruwapathirana, 2002). Kutinyu et al., (2014) reported that there was a reduction in fruit defects in all bagging treatments compared to uncovered bunch.

A banana bunch cover plays a very important role in influencing temperatures inside the bag. Economically, it is better to use thinner bunch covers as damage is bound to occur and plastic once damaged are unable to be reused again (Trochoulias,1975). Perforated covers were commonly used to reduce sunburn and damage for export of produce overseas (Daniells and Lindsay, 2005).

From the above sited information regarding the uses of bunch covers, it may be concluded that bunch covers has a lot of positive impact on improvement of banana cultivation in terms growth period, yield, quality and appearance. However, few experiments did not found covering much impactful but its usefulness cannot be neglected based on them. Thus, bunch covering may prove to be easy and cheap practice to be undertaken by the banana growers to achieve higher profits in an environment friendly way.

\section{References}

Amani, M. (2005). Effects of bunch covers on pests and diseases control of Banana (Musa acuminata L.) in Baluchestan. Sistan \& Baluchestan Organization of Jahad-E- Agriculture.

Amani, M. and Avagyan, G. (2014). Isolation and identification of fungal pathogens on banana trees (Musa acuminata L.) in Iran. Intern. J. Agri. Sci. 4: 409-413.

Amarante, C., Banks, N.H. and Max, S. (2002). Effect of preharvest bagging on fruit quality and postharvest physiology of pears (Pyrus communis). New Zealand J. Crop Hort. Sci. 30: 99-107.

Anonymous (1993). Effect of bunch cover on growth and yield of banana. Research Report All India coordinated Research Project on Tropical Fruits.

Anonymous (2003). Bunch covers for improving plantain and banana peel quality. National Agriculture Research Institute. Technical Bulletin No. 4.

Anonymous (2012). Annual Report by NRCB. Performance of 'Repol', a polypropylene based non-woven fabric as bunch sleeves on bunch characteristics and fruit quality in banana, Tiruchirapalli, Tamil Nadu.

Chao-Chihping; Hwang, S., Chiang, S.C., Tang, C.Y., Chao, C.P., Hwang S.C. and Galan-Sauco, V. (1998). An integrated approach for the prevention of uneven degreening of bananas in Taiwan. Acta Hort. 490: 511-518.

Choudhury, B.K., Kim, J., Kung, H.F. and Li, 
S.S. (1997). Cloning and developmental expression of Xenopus cDNAs encoding the Enhancer of split groucho and related proteins. Gene 195: 41-48.

Choudhury, H., Chandra, K. and Baruah, K. (1996). Effect of bunch cover on morphological parameters and yield of banana. Adv. Plant Sci. 9: 131-137.

Collins, J.L. (1960). The pineapple. Leonard Hill, London.

Cuneen, T. and McEntyre, C. (1988). Does the colour of banana bags have an effect on the yield of bananas and the climate inside the bag? Banana Bull. 52:14-15.

Daniells, J.W. (1994). The wild banana species of Papua New Guinea. RFC Newsl. 88: 55.

Daniells, J.W. and Lindsay, S. (2005). Banana fruit bunch covering. Mhtml: file://cover\% $20 \quad$ all banana\%20bunch\%20covering.mht, retrieved on 24.4.15.

Daniells, J.W., Watson, B.J., O'Farrell, P.J. and Mulder, J.C. (1987). Soil water stress at bunch emergence increases maturity bronzing of banana fruit. Queen. J. Agric. Anim. Sci. 44: 97100.

Dhua, R.S., Sen, S.K. and Bose, T.K. (1988). Physico chemical development in banana cv. Giant Governor during fruit growth and maturity. Prog. Hort. 20: $128-132$.

Gowen, S.R. (1995). Pests. In: Bananas and Plantains. Gowen, S. (ed). Chapman and Hall, London, pp. 382-402.

Green, G.C. and Kunhe, F.A. (1975). Physiological changes of banana with temperature. Agrochemoph. 9: 23-32.

Han, H.R., Moon, D.K., Kang, Y.K. and Lee, J.S. (1990). Effects of growth stage exposed to low temperature on growth and yield. J. Korean Soc. Hort. Sci. 31: 393-399.

Haque, M.A. (1984). Effect of planting time on the production of banana in Bangladesh. Bangladesh J. Agric. 9: 2332.

Harshash, M.M. and Al-Obeed, R.S. (2010). Effect of bunch bagging colour on yield and fruit quality of date palm. American-Eurasian J. Agric. Environ. Sci. 7: 312-319.

Hasan, M.A.; Bhattacharjee, S. and Debnath, U. (2001). Fruit quality and microclimate variation inside the bunch cover of Dwarf Cavendish banana (Musa AAA). Orissa J. Hort. 29: 46-50.

Heenan, D.P. (1973). Bunch covers for bananas in the Northern District Papua New Guinea. Agric. J. 24: 156-161.

Hewett, E.W. (2006). An overview of preharvest factors influencing postharvest quality of horticultural products. Intern. J. Postharv. Technol. Innov. 1: 4-15.

Irizarry, H., Rivera, E. and Rodriquez, J.A. (1992). Bunch and ratoon management for profitable production of high quality bananas (Musa acuminata, AAA). Agricultural Research Service-USDA, Mayaguez, Puerto Rico. pp. 123.

Jayaraman, K.S. and Ramanuja, M.N. (1986). Changes in polyphenoloxidase and other endogenous factors during ripening. J. Food. Sci. Tech. 24: 67-71.

Jia, H., Araki, E. and Okamato, G. (2005). Influence of fruit bagging on aroma volatiles and skin coloration of 'Hakuho' peach (Prunus paesicha Batsch). Postharv. Biol. Technol. 35: 61-68.

Johns, G.G. (1996). Effects of bunch trimming and double bunch covering on yield of bananas during winter in New South Wales. Australia J. Expt. Agricl. 36: 229-235.

Johns, G.G. and Scott, K.J. (1989). Delaying harvesting of bananas with sealed covers on bunches. Australia J. Expt. 
Agri. 20: 719-726.

Jones, D.R. (2000). Sigatoka leaf spot disease. In: Diseases of Banana, Abacá and Enset. Jones, D.R. (Ed.). CABI Publishing, Wallingford. pp. 79-92.

Khataniar, L. (1989). Effect of time of planting on banana cv. Jahaji (Cavendish sub group- AAA). M.Sc. (Agri) thesis, Assam Agricultural University, Jorhat.

Kothavade, D.V., Mahajan, P.R., Sanghavi, K.U. and Patil, D.R. (1985). Effect of leaf area on growth and yield of 'Basrai' Banana. South Indian Hort. 33: 122-123.

Kutinyu, R., Fraiser, C., Ngezimana, W. and Madau, F. (2014). Evaluation of banana bunch protection materials for optimum fruit production on cultivars grown in Mozambique. Trop. Agric. (Trinidad) 91: 2

Lizada, M.C.C., Pantastico, E.B., Shukor, A.R. and Sabari, S.D. (1990). Ripening of banana: changes during ripening in banana. In: Banana: Fruit development, Postharvest Physiology, Handling and Marketing in ASEAN. Hassan, A. and Pantastico, E.B (Eds.). ASEAN Food Handling Bureau, Kuala Lumpur, pp. 65-72.

Lodh, S.B., Ravel, P., Selvaraj, T. and Kohli, R.R. (1971). Biochemical changes associated with the growth and development of banana. Indian J. Hort. 28: 38-35.

Madhava Rao, V.N. (1984). Banana. First Ed., ICAR, New Delhi.

Marangoni, A.G., Palma, T. and Sanley, D.W. (1996). Membrane effects in postharvest physiology. Postharv. Biol. Technol. 7: 193-217.

Marriot, J. (1980). Bananas-physiology and biochemistry of storage and ripening for optimum quality. CRC Crit. Rev. Food Sci. Nutr. 13: 41-88.

Muchui, M.N., Mathooko, F.M. and Njoroge,
C.K. (2010). Effect of perforated blue polyethylene bunch covers on selected post-harvest quality parameters of tissue cultured bananas (Musa sp.) cv. Williams in Central Kenya. J. Stored Prod. Postharv. Res. 1: 41-45.

Mukherjee, U. (2006). Evaluation of insecticides and some eco-friendly approaches to manage scarring beetle, Basilepta subcostatum in banana. $J$. Appl. Zool. Res. 17: 54-56.

Nakasone, N.Y. and Paull, R.E. (1998).Tropical Fruits.CAB International, New York.

Nascimento, J.R.O., Junior, A.V., Bassinello, P.Z., Cordenunsi, B.R., Mainardi, J.A., Purgatto, E. and Lajolo, F.M. (2006). Beta-amylase expression and starch degradation during banana ripening. Postharv. Biol. Technol. 40: 41-47.

Nguyen Thuy, T.B., Ketsa, S. and van Doorn, W.G. (2003). Relationship between browning and the activities of polyphenol oxidase and phenylalanine ammonia lyase in banana peel during low temperature storage. Postharv. Biol. Technol. 30: 187-193.

Pathak, P.K. and Mitra, S.K. (2014). Assessment of low cost perforated polyethylene cover as non-chemical approach to control scarring beetle and quality banana production. Acta Hort. pp. 283-285.

Patil, B.A., Deshmukh, S.S. and Badgujar, C.D. (1989). Proc. Sixth Biennial workshop of AICRP on Tropical Fruits.

Pawlowski, K., Kunze, R., de Vries, S. and Bisseling, T. (1994). Isolation of total, poly (A) and polysomal RNA from plant tissues. In: Plant Molecular Biology Manual. Gelvin, S.B. and Schilperoof, R.A. (Eds.). Kluwer Academic Publishers, Dordrecht, Holland, 5: 1-13.

Purification and characterization of polyphenol oxidase from banana 
Purseglove, J.W. (1972). Tropical Crops, Dicotyledonous, Longman, London.

Reddy, S.A. (1989). Effect of bunch covers on bunch maturity and fruit size in high density 'Robusta' banana orchards. $J$. Res. 17: 81-82.

Robinson, J.C. (1993). Hand book of banana growing in South Africa. Institute for Tropical and Subtropical Crops, Nelspruit, South Africa.

Robinson, J.C. (1996). Bananas and plantains. Institute for Tropical and Subtropical Crops, University Press, Cambridge, pp.172-174.

Robinson, J.C. and Nel, D. (1982). The use of banana bunch covers during summer at Burger shall. Burger shall Experimental Farm, South Africa. Inform. Bull. Citrus Subtrop. Fruit Res. Inst. 118: 8-9.

Robinson, J.C. and Nel, D. (1984). Banana bunch covers effective in winter. Nelspruit, South Africa. Inform. Bull. Citrus Subtrop. Fruit Res. Inst. 138: 56.

Robinson, J.C. and Nel, D.J. (1986). The influence of planting date, sucker selection and density on yield and crop timing of banana cv. William in Eastern Transvall. Sci. Hort. 29: 347-358.

Rodrigues, G.H., Sunin, I., Pieris, A.V., Mendes, C.Q., Araujo, R.C. de; Packer, U., Riberiro, M.F. and Garage, L.V. (2008). Replacement of corn by citrus pulp in high grain diets to feedlot lambs. Ciencia Rur. Santa Maria 38: 789-794.

Rodrigues, M.G.V.; Souto, R.F. and Menegucci, J.L.P. (2001). Influence of polyethylene banana bunch cover for irrigated banana tree in the north of Minas Gerais state. Revista Brasileira de Fruticul. 23: 559-562.

Sarkar, S. (2014). Shooting harvest interval and physico-chemical properties of banana (Musa AAA cv. Grand Naine) in relation to micro climate inside the bunch cover. Asian J. Hort. 9: 40-42.
Sarmah, D.D. (1976). Varietal differences in the physic- chemical characteristics of banana fruit. Indian Agric. 20: 115-119.

Satyanarayana, M. (1985). Effect of number of functional leaves on growth and yield of banana. Madras Agric. J. 72: 532533.

Seymour, G.B., Taylor, J.E. and Tucker, G.A. (1993). Biochemistry of fruit ripening. Seymour, G.B. (ed). Chapman and Hall, London, pp. 83-106.

Shanmugasundaran, K.A. and Manavalan, R.S.A. (2002). Postharvest characteristics of 'Rasthali' bananas grown under different polyethylene covers. Infomusa. 11: 43-45.

Shanmugavelu, K.G. and Balakrishan, R. (1980). Growth and development of banana. Proc. of Nat. Seminar on Banana Production. Tech., TNAU, pp. 67-72.

Sharom, M., Willemot, C. and Thompson, J.E. (1994). Chilling injury induces lipid phase changes in membranes of tomato fruit. Plant Physiol. 105: 305-308.

Shewfelt, R.L. (1999). What is quality? Postharv. Biol. Technol. 15: 197-200.

Shewfelt, R.L. (2009). Measuring quality and maturity. In: Postharvest Handling - A systems approach. Academic Press, London, pp. 461-481.

Singh, R.K. (1976). Time of shooting and related yield of banana varieties Alpan and Malbhog. Proc. Bihar Acad. Agri. Sci. 24: 39-44.

Soenapa, M., Laswai, H.S.M. and Fernado, S.P. (1986). Availability of L. Ascorbic acid in Tanzanian banana. J. Food Sci. Technol. 23: 293-295.

Stevenson, D. (1976). What colour to select for banana bunch covers. Banana Bull. 40: 2 .

Stover, R.H. (1972). Banana, plantain and abaca diseases. Commonwealth Mycological Institute, Kew, Surrey. 
Stover, R.H. and Simmonds, N.W. (1987). Bananas. Third Edition, Longmans, London. p. 67.

Swennen, R. and Lanhe, E.De. (1985). Growth parameters of yield of plantain. Ann. Bot. 56: 197-204.

Tripathi, V.K., Ram, H.B; Jain, S.P and Sing, S. (1981). Changes in developing banana fruit. Progr. Hort. 13: 45-53.

Trochoulias, T. (1975). Longevity of polyethylene bunch covers for bananas in relation to thickness of the film. Banana Bull. 52: 281-283.

Turner, D.W. (1984).Bunch covers for bananas. Agfact H. 6: 78.

Turner, D.W. (1997). Bananas and plantains. In: Postharvest physiology and storage of tropical and subtropical fruits. Mitra,
S.K (Ed.). Oxon, CAB International, pp. 47-83.

Turner, D.W. and Lahav, E. (1983). The growth of banana plant in relation to temperature. Australian J. Plant Physiol. 10: 43-53.

Weerasinghe, S.S. and Ruwanpathirana, K.H. (2002). Influence of bagging material on bunch development of banana (Musa spp.) under high density planting system. Ann. Sri Lankan Dept. Agric. 4: 47-53.

Yang, C.P., Shuji, F., Ashrafuzzaman, M.D., Nakamura, N. and Hayashi, N. (2000). Purification and characterization of polyphenol oxidase from banana (Musa sapientum L.). Pulp. J. Agric. Food Chem. 48: 2732-2735.

\section{How to cite this article:}

Purnima Pathak, Ranjit Kumar Bhattacharyya, Bhupen Kumar Baishya, Utpal Das and Jugabrata Das. 2017. A Review of Works Done Regarding the Impact of Bunch Cover Application in Banana. Int.J.Curr.Microbiol.App.Sci. 6(7): 2181-2194. doi: https://doi.org/10.20546/ijcmas.2017.607.256 